\title{
Natural substrata for corticioid fungi
}

\author{
EUGENE O. YURCHENKO \\ Laboratory of Mycology, V.F. Kuprevich Institute of Experimental Botany \\ Akademichnaya 27, BY 220072, Minsk \\ fungi@biobel.bas net.by
}

Yurchenko E.O.: Natural substrata for corticioid fungi. Acta Mycol. 42 (1): 113 124, 2006.

The paper reviews the types of substrata inhabited by non poroid resupinate Homobasidiomycetes in situ in global scale with both examples from literature sources and from observations on Belarus corticioid fungi biota. The groups of organic world colonized by corticioid basidiomata and vegetative mycelium are arboreous, semi arboreous, and herbaceous vascular plants, Bryophyta, epiphytic coccoid algae, lichenized and non lichenized fungi, and occasionally myxomycetes and invertebrates. The fungi occur on living, dying, and dead on all decay stages parts of organisms. Besides, the fungi are known on soil, humus, stones, artificial inorganic and synthetic materials and dung.

Key words: Bryophyta, Corticiaceae, herbs, lichens, litter, woody plants

\section{INTRODUCTION}

Corticioid fungi (Homobasidiomycetes) is an artificial union of life forms, the assembling of which is based mostly on basidioma morphological organization similarity. Our definition of corticioid basidiomata sensu lato includes the types of fructifications ranged from totally resupinate to effuse-reflexed with rather wide effused part in most cases, and from loose arachnoid to crustose and membranaceous in consistency; the hymenophore shape varies from smooth to almost poroid (reticulate or irpicoid) and long-toothed. Some mycologists still use for them rather convenient name Corticiaceae s. l. According to the recent molecular phylogeny-based systems the species of corticioid fungi are distributed among the orders Agaricales, Boletales, Cantharellales, Ceratobasidiales, Hymenochaetales, Phallales, Polyporales, Russulales, Stereales, Thelephorales (Kirk et al. 2001) or between athelioid, bolete, cantharelloid, corticioid, euagarics, Gloeophyllum, gomphoid-phalloid, hymenochaetoid, polyporoid, russuloid, thelephoroid, and trechisporoid clades sensu Binder et al. (2005).

Corticioid fungi are a very significant group of wood decay organisms. The type of nutrition for no less than $80 \%$ of species is lignin degradation that means ultimately the transformation of dead wood into humus substances, and ca $5 \%$ of species cause 
cellulose decay. Besides, there are mycorrhiza-forming species and a part of species which are able to decay different soft plant debris in litter. The facts of Corticiaceae s. l. growth on non-wood substrata were documented by different authors, but still the data are strongly dispersed.

The term substratum according to Hawksw orth et al. (1995: 445) means 'the material on which an organism is growing or to which it is attached'. In the first case we tell about nutritive substratum, in the second - about attachment substratum. Since fungal thallus contacts with great number of different particles we use the term in more strict sense - the body to which the fungus attach by its basidioma basal part or vegetative mycelium, or in which fungal hyphae penetrate. Thus the cases of mechanical embracing of outer particles by upper layers of big fruitbodies are excluded (for example, we observed the embracing of living Fragaria vesca L. tendrils by growing Chondrostereum purpureum (Pers.) Pouzar, MSK 6519).

Different substrata for Corticiaceae s. l. in situ are discussed in sections below.

The specimens examined are kept in V.F. Kuprevich Institute of Experimental Botany Herbarium, section "Fungi" (MSK-F).

Photographs were made by Olympus Camedia C-5060 digital camera via Olympus SZ61 stereomicroscope and Olympus BX51 microscope; and also by Nikon Coolpix 4500 digital camera directly or via Nikon Eclipse E200 microscope with objective magnification $4 \times$. Microscopic preparations for passing light were made in $5 \% \mathrm{KOH}$ solution.

The correct names of fungi collected in Belarus follow CORTBASE vers. 2 (Pa r masto et al. 2004) and Kõljalg (1996); in referring to publications the original names are cited, with the orthography checked via CORTBASE.

\section{VASCULAR PLANTS}

Corticiaceae s. 1. are known on all kinds of woody plants - angiosperms, gymnosperms, and arboreous ferns (Tubulicium vermiculare (Wakef.) Boidin \& Gilles and T. dussii (Pat.) Oberw. fide Domański 1992). Main substrata are tree trunks and branches. Rather big number of species occur regularly or occasionally on processed or man-transformed wood (timbers, fences, woodwork, chips), but commonly exposed to open air. For instance, Aandstad and Ryvarden (1987) listed 82 species on wood fences in Norway. The number of species growing indoor is much less - e.g. Bondartsev (1948) reported 9 house fungi collected in big city.

A number of species are known from small shrubs - Arctostaphylos, Chamaecytisus, Cistus, Duschekia, Erica, Genista, Ledum, Pentaphylloides, Sarothamnus, Thymus (including strictly specialized Coronicium thymicola (Bourdot \& Galzin) Jülich), Vaccinium (e.g. two species described only from this genus - Laeticorticium efibulatum M.J. Larsen \& Nakasone and Peniophora sphaerocystidiata Burds. \& Nakasone), and woody lianas, like Actinidia and Vitis (Jülich 1984; Domański 1988, 1991, 1992; Kõljalg 1996). Among small shrubs rather rich species collection is reported on Calluna stems and twigs: Acanthobasidium norvegicum (J. Erikss. \& Ryvarden) Boidin, Acanthophysium apricans (Bourdot) G. Cunn., Corticium macrosporopsis Jülich, Hyphodontia hastata (Litsch.) J. Erikss., Phanerochaete ericina (Bourdot) J. Erikss. \& Ryvarden, Ph. martelliana (Bres.) J. Erikss. \& Ryvarden, Sistotrema dennisii Malençon - on living stem bases, Stereum rameale (Pers.) Fr., Trechispora 
praefocata (Bourdot \& Galzin) Liberta (Domański 1988, 1991, 1992). Peniophora halimi Boidin \& Lanquetin and Radulomyces rickii (Bres.) M.P. Christ. inhabit stems of shrubby halophyte Atriplex halimus L. (D o m ańs ki 1991). Among our collections there are Amphinema byssoides (Pers.) J. Erikss. (MSK 5730), Piloderma fallax (Liberta) Stalpers (MSK 6098), and Tomentella terrestis (Berk. \& Broome) M.J. Larsen (MSK 6299) on living and dead Vaccinium myrtillus L. stems, immersed in litter.

Some species also occur on semi-arboreous plants, i.e. those with every year dying younger sprouts. On Rubus idaeus L. and R. nessensis W. Hall dead stems we collected in Belarus Ceratobasidium cornigerum (Bourdot) D.P. Rogers, Peniophora cinerea (Pers.) Cooke, P. incarnata (Pers.) P. Karst., Phanerochaete sanguinea (Fr.) Pouzar, Phlebiella sulphurea (Pers.) Ginns \& Lefebvre, Radulomyces confluens (Fr.) M.P. Christ., and Tomentella spp. Other saprobic species known on Rubus are Acanthobasidium norvegicum, Corticium macrosporopsis Jülich, Peniophora meridionalis Boidin, Phanerochaete tuberculata (P. Karst.) Parmasto, Sistotrema pteriphilum K.H. Larss. \& Hjortstam, Tomentella coerulea (Bres.) Höhn. \& Litsch., and T. ellisii (Sacc.) Jülich \& Stalpers (D o mańs ki 1988, 1991, 1992; Kõljalg 1996). Litschauerella clematitis (Bourdot \& Galzin) J. Erikss. \& Ryvarden, Peniophora pseudoversicolor Boidin, and Raduomyces rickii were published from Clematis (D o m ańs ki 1991). Partly lignified Arundinaria and Sasa serve as hosts for Acanthobasidium phragmitis Boidin \& al., Cyphellathelia pezizoidea (Ellis \& Everh.) Jülich, and Tomentella sublilacina (Ellis \& Holw.) Wakef. (Domański 1988; Kõljalg 1996).

Several corticioid fungi are known from succulent perennial plants, e.g. Athelia decipiens (Höhn. \& Litsch.) J. Erikss., Hyphoderma fouquieriae Nakasone \& Gilb., Peniophora tamaricicola Boidin \& Malençon, Phanerochaete omnivorum (Shear.) Burds. \& Nakasone, Ph. tuberculata on cacti Carnegiea and Opuntia, Crustoderma opuntiae Nakasone \& Gilb. and Uncobasidium calongei (Tellería) Hjortstam \& Tellería described only from Opuntia, and Laetisaria agaves Burds. \& Gilb. on Agave leaves (Nakasone, Gilbertson 1978; Domański 1988, 1992).

The degree of specialization to vascular hosts varies for corticioid fungi species in wide limits. In Belarus only eleven species are still found to be strictly specialized to single plant and regularly recorded on it: Amylostereum laevigatum (Fr.) Boidin (on Juniperus communis L.), Corticium quercicola Jülich (on Quercus robur L.), Meruliopsis taxicola (Pers.) Bondartsev (on Pinus sylvestris L.), Peniophora laeta (Fr.) Donk (on Carpinus betulus L.), P. limitata (Chaillet.) Cooke (on Fraxinus excelsior L.), P. pini (Schleich. \& DC.) Boidin (on Pinus sylvestris), P. polygonia (Pers.) Bourdot \& Galzin (on Populus tremula L.), P. rufomarginata (Pers.) Litsch. (on Tilia cordata Mill.), Phlebiella pseudotsugae (Burt) K.H. Larss. \& Hjortstam (on Pinus sylvestris), Punctularia strigosozonata (Schwein.) P.H.B. Talbot (on Populus tremula), Sistotremastrum suecicum Litsch. (on Pinus sylvestris). It shows uneven distribution of highly specialized fungi over the genera, with big per cent among Peniophora species. Several species are genera-specialized, e.g. Peniophora erikssonii Boidin recorded on Alnus glutinosa (L.) Gaertn. and A. incana (L.) Moench, and Vuilleminia alni Boidin, Lanquetin \& Gilles on the same two hosts. Concerning Peniophora pini mentioned above, outside of Belarus it was collected on other Pinus species; we examined specimens from P. kochiana Klotzsch (Russian Caucasus, MSK 6566) and P. nigra Arnold (Čech Republic, collected by W. Wojewoda, KRAM-F 53637). 
The other type of specialization is the occurrence of a fungus frequently on one host and very rarely on more 1-2 hosts - like Peniophora quercina (Pers.) Cooke frequently on Quercus robur and once on Corylus avellana L. (MSK 4562) in our collections. A clear distinguishing group of fungi when consider substratum specialization are inhabitants of coniferous species only. In Belarus the species still recorded on Picea abies (L.) Karst. and P. sylvestris only are Amylostereum chailletii (Pers.) Boidin, Hyphodontia alutacea (Fr.) J. Erikss., Phlebiopsis gigantea (Fr.) Jülich, Pseudomerulius aureus (Fr.) Jülich, and Serpula himantioides (Fr.) P. Karst.

Contrary, several species have very wide range of hosts, e.g. a good represented in MSK-F herbarium Peniophora cinerea (211 specimens from Belarus) was recorded in Belarus on 44 vascular hosts: Acer japonicum Thunb., A. platanoides L., Aesculus hippocastanum L., Alnus glutinosa, A. incana, Amelanchier ovalis Medik., Betula pendula Roth, B. pubescens Ehrh., Carpinus betulus, Cerasus vulgaris Mill., Chamaenerion angustifolium (L.) Scop., Corylus avellana, Fagus sylvatica L., Frangula alnus Mill., Fraxinus excelsior, Fraxinus sp., Ligustrum vulgare L., Lonicera xylosteum L., Malus domestica Borkh., M. domestica $\times$ prunifolia, M. × prunifolia (Willd.) Borkh., M. sylvestris Mill., Padus avium Mill., Populus tremula, Prunus domestica L., Pyrus communis L., P. domestica Medik., Quercus borealis Michx. f., Q. robur, Ribes nigrum L., R. rubrum L., Rosa cf. subcanina (Christ) Dalla Torre \& Sarnth., Rosa sp., Rubus nessensis, Salix caprea L., S. cinerea L., Sorbus aria (L.) Crantz, S. aucuparia L., S. hybrida L., Syringa vulgaris L., Tilia cordata, plus on debris of three unidentified herbaceous species near wood. Such rich list of substrata is explained also by the wide ecological amplitude in respect to biotope types. Species like Peniophora cinerea and $P$. incarnata commonly found in ornamental woody plantations and dendrological collections, which extends their opportunities to colonize exots. Though, we have not collections of $P$. cinerea from gymnosperms. Similar multi-host behavior was observed for Radulomyces confluens, collected on Amelanchier ovalis, Armeniaca vulgaris Lam., Caragana arborescens Lam., Cerasus vulgaris, Crataegus sp., Fraxinus excelsior, Malus domestica, M. domestica $\times$ prunifolia, M. × prunifolia, M. sylvestris, Padus avium, Picea abies, Prunus divaricata Ledeb., P. domestica, Pyrus communis, P. domestica, Quercus robur, Ribes nigrum, Rubus idaeus, Sorbus aucuparia.

In respect to wood decomposition the fungi inhabit it on all decay stages from still living and starting to decay to almost transformed into humus.

Still not clear studied subject is the relation of fungi to living, dying, and recently dead tissues of vascular plants as substratum. Not so easy to delimit the border between biotrophy, necrotrophy, and saprotrophy for wood-inhabiting fungi. Our purposeful search of Corticiaceae s. 1. on living parts of trees has shown that the list of species is bigger than it was documented by previous workers. The most often event is basidiomata patches found on trunk wound calluses, i.e. roller-shaped excrescences around former wounds, covered by thin bark with rather chlorophyll-rich cells in cortex parenchyma. The fungi which were found in former wounds simultaneously on dead wood and on surrounding living tissues in Belarus are Byssomerulius corium (Pers.) Parmasto, Coniophora puteana (Schumach.) P. Karst., Cylindrobasidium evolvens (Fr.) Jülich, Hymenochaete tabacina (Sowerby) Lév., Hyphodontia crustosa (Pers.) J. Erikss., H. sambuci (Pers.) J. Erikss., Hypochnicium bombycinum (Sommerf.) J. Erikss., Lagarobasidium detriticum (Bourdot) Jülich, Peniophora cinerea, P. incarnata (Fig. 1), Phanerochaete sordida (P. Karst.) J. Erikss. \& Ryvarden, Phle- 
bia aurea (Fr.) Nakasone, Ph. tremellosa (Schrad.) Nakasone \& Burds., Steccherinum fimbriatum (Pers.) J. Erikss., Stereum hirsutum (Willd.) Gray. Several species were also collected from bark on the borded of dead and living tissues of trunk and branches: Hyphoderma mutatum (Peck) Donk, H. setigerum (Fr.) Donk, Peniophora nuda (Fr.) Bres., Phlebia radiata Fr., Radulomyces confluens.

Besides trunks and branches, corticioid fungi are found on all kinds of woody plant organs, including roots, tendrils (Fig. 2), and fallen parts - bark pieces, leaf plates and petioles, fruits, cones. On fallen female cones of Picea and Pinus we collected common litter fungi Amphinema byssoides, Athelia epiphylla complex, Phlebiella sulphurea, and more rarely Tylospora asterophora (Bonord.) Donk; Ceratobasidium cornigerum was found on cone peduncle. Besides, Tylospora fibrillosa (Burt) Donk was collected on fallen male cones of Pinus sylvestris (Fig. 3).

Several species are parasitic on tree leaves - Ceratobasidium ramicola C.C. $\mathrm{Tu}$, D.A. Roberts \& Kimbr., Corticium stevensii Burt, and Koleroga noxia Donk (Domański 1991). Ceratobasidium cornigerum-like species, published under the name Ceratobasidium aff. ramicola C.C. Tu, D.A. Roberts \& Kimbr. (Yurchenko 2003), was found fructifying on living Juniperus communis needles.

According to Jülich (1984) 20 species inhabit fallen angiosperm leaves, among them six species of Athelia and three of Byssocorticium; Dacryobasidium lutescens (J. Erikss. \& Ryvarden) Jülich was described from decaying leaves only. Domański $(1988,1991,1992)$ reported 20 saprobic species on angiosperms leaves and 7 species on fallen needles. This group includes Trechispora gillesii (Maas Geest.) Liberta and Tubulicium capitatum (D.P. Robers \& Boquiren) Burds. \& Nakasone described from dead leaves only, the lattest species from palms, and Leptosporomyces galzinii (Bourdot) Jülich sometimes inhabiting fallen leaves submerged in stream water.

The list of species collected by us on fallen leaves of angiosperms includes Amphinema byssoides, Athelia arachnoidea (Berk.) Jülich, A. epiphylla complex, Botryobasidium laeve (J. Erikss.) Parmasto, Hyphodontia floccosa (Bourdot \& Galzin) J. Erikss., Leptosporomyces galzinii, Phanerochaete sanguinea, Ph. sordida, Steccherinum fimbriatum, Tylospora fibrillosa. Besides, several fungi were observed on fallen leaves adhered to decaying wood debris - Botryobasidium subcoronatum (Höhn. \& Litsch.) Donk, Chondrostereum purpureum, Cylindrobasidium evolvens, Peniophora cinerea (Fig. 4) or to old polypore pileus - Sistotrema brinkmannii (Bres.) J. Erikss. (Fig. 5). The species collected by us on fallen coniferous needles are Amphinema byssoides, Athelia epiphylla complex, Phanerochaete sanguinea, Piloderma fallax, Sistotrema brinkmannii, Tomentella fuscocinerea (Pers.) Donk.

Several corticioid species are important inhabitants of plant rhizosphere in boreal forests, forming ectomycorrhiza, especially Piloderma byssinum (P. Karst.) Jülich and $P$. fallax. Thanatephorus pennatus Currah and Ypsilonidium sterigmaticum (Bourdot) Donk (in state of Rhizoctonia) were isolated from mycorrhizal roots of orchids (Dom ańs ki 1992). Ceratobasidium cornigerum in state of Rhizoctonia goodyerae-repentis auct. was isolated as endophyte from orchid roots (Wa rcup, Talbot 1966). We observed a complex of Amphynema byssoides and Tomentella vegetative hyphae associated with Vaccinium myrtillus roots (Fig. 6).

Domański $(1988,1991,1992)$ classifies 10 species in Corticiaceae s. 1. as litterinhabiting or colonizing different debris on soil. Some of plant debris decay fungi 
have the ability to envelope by their basidiomata any meeting substratum, e.g. Corticium boreoroseum Boidin \& Lanquetin.

The same author $(1988,1991,1992)$ reported 18 species known from herbaceous stems and herb remains, including leaves. E.g. Acanthobasidium delicatum (Wakef.) Oberw., Epithele typhae (Pers.) Pat., and Hypochnicium detriticum were documented for Cyperaceae leaves. There are several species described in literature, specialized to inhabit some herbs, e.g. on Cyperaceae (Acanthobasidium delicatum), on Monocotyledoneae (Epithele typhae, Phlebiella aurora (Berk. \& Broome) K.H. Larss. \& Hjortstam), on Poaceae (Acanthobasidium phragmitis), on Saccharum (Phanerochaete sacchari (Burt.) Burds.), on Typha (Hyphoderma typhicola (Burt.) Donk; Jülich 1984; Domański 1988, 1991). Tomentella cladii Wakef. is reported by Jülich (1984) on Cladium mariscus (L.) Pohl. only and Tomentella juncicola Svrček on Juncus only. The species known on Equisetum are Athelopsis lembospora (Bourdot) Oberw., Hypochnicium detriticum, and Sistotrema pteriphilum K.H. Larss. \& Hjortstam (Domański 1988, 1992).

We collected fungi on dead stems of Chamaenerion angustifolium (Ceratobasidium aff. pseudocornigerum M.P. Christ., Peniophora cinerea, Sistotrema octosporum (J. Schröt.) Hallenb.) and Humulus lupulus L. (Aleurodiscus cf. cerussatus (Bres.) Höhn. \& Litsch., MSK 4963). Chamaenerion angustifolium was mentioned as host for Tomentella coerulea (Kõljalg, 1996). Besides, dead herbaceous stems attached to dead wood and bark were observed to be covered by fruitbodies of Peniophora cinerea (MSK 5287), and Phanerochaete sordida (MSK 6619). The colonization of dead grass blades arranged closely to wood was recorded for Botryobasidium candicans J. Erikss. (MSK 4433), Hyphoderma mutatum (MSK 4098), H. setigerum (MSK 4431b), Peniophora cinerea (MSK 4573, 5287), and Phanerochaete sanguinea (4459).

There are several species of Ceratobasidium and Thanatephorus occurring on living herbs and belonging to economically meaningful crop pathogens, though their parasitic activity is sometimes controversial. Among them there are Ceratobasidium oryzae-sativae P.S. Gunnell \& R.K. Webster and C. setariae (Sawada) P.S. Gunnell \& R.K. Webster on rice and other crops (Gunnell, Webster 1987); Thanatephorus corchorus C.C. Tu et al. causing damping-off of Corchorus capsularis L. ( Tu et al. 1977); Thanatephorus cucumeris (A.B. Frank) Donk - the most studied and known from over 200 hosts, mostly herbaceous ones, occurring mostly on stem bases and roots (Daniels 1963); Th. praticola (Kotila) Flentje growing on vegetables (de Silva \& Wood 1964). Besides, Athelia rolfsii (Curzi) C.C. Tu \& Kimbr. in state of Sclerotium rolfsii Sacc. causes leaf and stem blights and fruit damage of many hosts (Punja et al. 1982; Tu et al. 1992).

Other herb parasites are Limonomyces roseipellis Stalpers \& Loer. and L. culmigenus (J. Webster \& D.A. Reid) Stalpers \& Loer. on Poaceae and Cyperaceae (Domański 1991) and Thanatephorus langlei-regis D.A. Reid described from Plantago lanceolata L. (Reid 1969). Thanatephorus orchidicola Warcup \& P.H.B. Talbot is known from living orchids (Wa rcup, Talbot 1966), but also was found on living fern (Kotiranta, Sa arenoksa 1993).

Herbaceous Pteridiophyta sometimes draw special attention as substratum for Corticiaceae s. 1., e.g. Hjor ts ta m \& Lars s on (1997) list 79 species on ferns. Handbook by Jülich (1984) reports 16 saprobic species on ferns, among them Mycostigma aegeritoides (Bourdot \& Galzin) Jülich, Parvobasidium cretatum (Bourdot \& Gal- 
zin) Jülich, Pteridomyces galzinï (Bres.) Jülich, and Repetobasidiellum fusisporum J. Erikss. \& Hjortstam known only from fern fronds, especially rhachises. Hj or $\mathrm{ts}$ t a m et al. (1988: 1471) indicate Phlebiella filicina (Bourdot) K.H. Larss. \& Hjortstam as obligate fern inhabitant. D o mański $(1988,1991,1992)$ reported 26 species on herbaceous fern organs and fern debris, among them Pteridomyces bananisporus Boidin \& Gilles and P. capitatus Boidin \& Gilles described from ferns only, and Athelia pyriformis (M.P. Christ.) Jülich known on living ferns. Tubulicium vermiculare was found on both herbaceous and arboreous ferns. Two specimens from this ecological group were collected in Belarus on dead fronds - Phanerochaete sordida (MSK 6619) and Sistotrema sp. (MSK 5564).

\section{BRYOPHYTA}

The substratum associations of fungi with true mosses and hepatics are rather rich, but not enough documented by corticiologists. The fungi found on living mosses can be classified into the two groups: embracing moss sprouts close to dead wood or bark, where the basidioma grows (Fig. 7, 8) and occupying sprouts without clear connection of basidiomata with wood (Fig. 9). Evidently for a number of fungi moss sprouts serve for enlarging spore-producing surface and uplifting them above the ground. But in process of fungus-moss interaction a part of living moss organs become deformed, agglutinated and chlorophyll-less, indicating the evident negative fungus effect (Fig. 7).

A list of 19 species found on mosses can be extracted from Jülich's handbook (1984), from which Tomentella brevispina is reported on moss only. Ceratobasidium bicorne J. Erikss. \& Ryvarden was published as known only from living Polytrichum (Eriksson, Ryvarden 1973). Domański (1988, 1991) reported 24 species on mosses including Lindtneria leucobryophila (Henn.) Jülich, described on this substratum only, and lichenized fungi Athelia phycophila Jülich (known from moss only), Dictyonema irpicinum Mont., D. moorei (Nyl.) Henssen, D. pavonia (Sw.) Parmasto, D. sericeum (Sw.) Berk.

Bryophyta come into interaction with fungi from the earliest ontogenetic stages, e.g. we observed the association of living embryo states of unknown moss with Tomentella sublilacina (Ellis \& Holw.) Wakef. hyphae on Picea abies bark (MSK 6570).

In a previous paper (Yurchenk 2001) we described the associations of 35 corticioid fungi with 11 moss species. The most common union with Bryophyta forms Amphinema byssoides, which hyphal strands, basidiomata patches and individual hyphae occur on living and dead lower parts of ground mosses Hylocomium, Pleurozium, and Ptilium. The same habitat is frequently occupied by Athelia epiphylla complex. Frequent moss sprouts colonization is observed for fungi with actively growing hyphal strands and rhizomorphs, e.g. Phanerochaete spp. and Steccherinum fimbriatum. The biggest number of fungal species was collected in association with the genus Brachythecium. Lophocolea heterophylla (Schrad.) Dum. is a wood-inhabiting hepatic which living thalli most frequently overgrown by corticioid fungi, e.g. Tomentella fuscocinerea, Tubulicrinis subulatus (Bourdot \& Galzin) Donk (Fig. 7), and Tylospora fibrillosa. 


\begin{abstract}
ALGAE
The substratum relations with algae is very poorly known phenomenon. The most prominent example is Athelia arachnoidea, causing lesions in algal films covering bark of trees and bushes, and described in details by us (Yurchenko, Golubkov 2003). Evidently other fungi are able to colonize epiphytic algae cover, but without such destructive activity, e.g. Hyphodontia rimosissima (Peck) Gilb. which fruitbody was found growing in some areas on well discernible layer of green coccoid algae (Fig. 10).
\end{abstract}

\title{
LICHENIZED FUNGI
}

The inhabitation of lichens by Corticiaceae s. 1. is also poorly documented. The species mentioned on living and dead lichens in main handbooks are Amphinema byssoides, Athelia epiphylla s. 1. (Athelia epiphylla Pers., A. salicum Pers.), and Sistotrema muscicola (Pers.) S. Lundell (Erikss on, Ryvarden 1973; Jülich 1984; D om ański 1988, 1992). The active parasitizing of living lichens is known for us for Athelia arachnoidea only. Rypaček (1967) discussed the antibiotic action of lichens on wood decay fungi in natural environment. He concluded that lichen metabolites, mostly lichen acids, supress mycelial growth and enzymatic activity of fungi in wood. Nevertheless, we observed a number of resupinate non-poroid Homobasidiomycetes coming into dense interaction with lichen thalli, e.g. Botryobasidium candicans, Cylindrobasidium evolvens, Peniophora cinerea (Fig. 11), P. nuda (Fig. 12), Phlebiella sulphurea, Schizopora paradoxa (Schrad.) Donk, Sistotrema brinkmannii, Sistotremastrum suecicum.

\section{NON-LICHENIZED FUNGI AND MYXOMYCETES}

Corticiaceae s. 1. were observed on various taxonomic groups of other fungi, including ascomycetes, polyporoid and agaricoid homobasidiomycetes, and conidiomata of anamorphic fungi.

Pyrenomycete stromata serve as substratum e.g. for Hyphoderma setigerum (on Daldinia concentrica (Bolton) Ces. \& De Not., MSK 6210; also Yu rchenko, Zmitrovich 2001) and Peniophora cinerea (on Diatrypella favacea (Fr.) Ces. \& De Not., MSK 6430). Xenasma aculeatum C.E. Gómez was reported on Hypoxylon ascomata (Domański 1992). Sometimes corticioid basidiomata occupy apothecia and subiculum of discomycetes, e.g. Tapesia (Fig. 13). Corticium quercicola was reported to be regularly associated with old Colpoma ascomata (Jülich 1984).

The inhabiting of decaying basidiomata of one fungus by another growing fungus is rather well known phenomenon for wood-inhabiting Aphyllophorales in general. The highest ability to colonize other aphyllophoroid fungi we observed for Sistotrema brinkmannii: it occurred on Fomitopsis pinicola (Sw.) P. Karst. (MSK 6419), Ganoderma lucidum (Curtis) P. Karst. (MSK 6212), Peniophora incarnata (MSK 4543), P. quercina (MSK 6296), resupinate Phellinus sp. (MSK 5804), and Stereum hirsutum (MSK 5771).

Sometimes substratum relations between two corticioid fungi can be rather complicated, e.g. the fruitboidies grow on each other in different areas. Example shown on Figure 14 is Hymenochaete tabacina occupying Peniophora nuda basidioma, but in the center of photo a patch of $P$. nuda margin going on $H$. tabacina is visible. 
Two fungi are known as evidently specialized parasites on other Corticiaceae s. 1.: Galzinia forcipata Pouzar on Elaphocephala and Laetisaria arvalis Burds. hyperparasitic on Thanatephorus cucumeris (D o mański 1988, 1991).

Polypores are frequently occupied by resupinate non-poroid Homobasidiomycetes, which was reflected in many publications, e.g. 33 species were listed by Bes1 et al. (1989). Jülich (1984) reported 7 species growing on old polypore fruitbodies. Large polypores not rarely are used by corticioid fungi as main nutritive substratum. For instance, a fruitbody of Phanerochaete laevis (Pers.) J. Erikss. \& Ryvarden totally overgrowing Fomes fomentarius (L.) J.J. Kickx hymenophore is shown on Fig. 15.

Associations with agarics is more rare event. Marasmius androsaceus (L.) Fr. rhizomorphs and pileus-less stipes is a common component of coniferous forest litter in Belarus, and e.g. Hyphodontia breviseta (P. Karst.) J. Erikss. (MSK 6222) was recorded on this substratum. Colonization of Armillaria spp. rhizomorphs attached to decaying wood was observed for Amphinema byssoides (MSK 4473) and Hyphoderma praetermissum (P. Karst.) J. Erikss. \& Å. Strid (Fig. 16).

Anamorphic fungi fruitbodies as substratum for corticioid fungi are still neglected by mycologists. An example is Peniophora cinerea several times observed on growing or decaying Exosporium tiliae Link conidiomata on dead Tilia cordata branches (Yurchenko 2001). Peniophora incarnata was also recorded once on Exosporium (Fig. 17; coll. Ye. Rotkina). Pycnidia of mitosporic fungi occurring on decaying wood are rather frequently enveloped by corticioid basidiomata. Among our collections are Sistotremastrum niveocremeum (Höhn. \& Litsch.) J. Erikss. covering spore-producing and destroying pycnidia of Chaetodiplodia sp. (MSK 4716) and Tubulicrinis subulatus on Diplodia-like fungus (Fig. 18).

Very rarely corticioid fungi occur on myxomycetes. Among our collections is Peniophora incarnata (MSK 4618) totally overgrowing a group of myxomycete sporocarps on wood.

\section{SOIL AND HUMUS}

The collective of corticioid species inhabiting soil is rather numerous, but they in general bulk are neglected in lists reviewing local mycobiotas. Commonly such species also inhabit litter. Their fructifications occur especially in soil interstices, e.g. mammal burrows. Some species belong to the fungi regularly occurring in upper soil layer, e.g. Piloderma fallax and Tylospora fibrillosa. The observations of Piloderma fallax in Belarus permit to classify it more strictly as lower litter horizon fungus. The list of fungi growing on ground and humus extracted by us from Jülich's handbook (1984) includes 28 species, from which 3 species belong to the genus Byssocorticium, 10 species to Tomentella, and 4 species to Tomentellastrum; the species Tomentella fragilis (Bourdot \& Galzin) M.J. Larsen, T. nitellina Bourdot \& Galzin, Tomentellastrum fuscocinereum (Pers.) Svrček, T. litschaueri (Svrček) M.J. Larsen are reported only on soil and humus. Domański $(1988,1991,1992)$ listed on soil and humus 27 species, including 4 species of Sistotrema, 4 species of Trechispora, lichenized Athelia andina Jülich, Dictyonema pavonia, and D. sericeum, and the fungi reported only on soil or in soil: Conohypha terricola (Burt) Jülich, Echinotrema clanculare Park.-Rhodes, Sistotrema hypogaeum Warcup \& P.H.B. Talbot, Waitea circinata Warcup \& P.H.B. Talbot. The remarkable observations of Peniophora lauta H.S. Jacks. and Tomentella 
fusca (Pers.) Schröt. fructifications on soil clods in cultivated fields were made by Warcup and Talb ot (1963). Occasionally typical wood fungi occur on soil particles close to decaying wood, as Peniophora incarnata (MSK 4682).

\section{MINERAL SUBSTRATA}

Several species were reported from stone surface in natural circumstances: Athelia andina, Piloderma lapillicola Jülich, Scopuloides hydnoides (Cooke \& Massee) Hjortstam \& Ryvarden, Tomentella calcicola (Bourdot \& Galzin) M.J. Larsen, T. subcinerascens Litsch., Tomentellastrum caesiocinereum Svrček (J ülich 1984; D om ański 1992). Tomentella radiosa (P. Karst.) Rick was reported on sand (Kõljalg 1996). We collected Tomentella bryophila (Pers.) M.J. Larsen underside of limestone piece in Crimean forest (MSK 5985).

House fungi are known to be colonizing artificial stony materials, e.g. Coniophora marmorata Desm. (Jülich 1984) and Serpula lacrymans (Wulfen) J. Schröt. (MSK 12127) were observed on concrete. Growth of S. lacrymans is known on different calcium-containing mineral materials (Bech-Andersen 2005), bricks, oven clay, and even on glazed tile (Bondartsev 1948). Leucogyrophana olivascens (Berk. \& M.A. Curtis) Ginns \& Weresub (MSK 4945) was collected on mixed substratum of sand, subclay, and brick pieces in cellar.

\section{OTHER SUBSTRATA}

There are several exotic substrata not mentioned above. Apples at store are colonized by Athelia rolfsii (Punja 1982) and Butlerelfia eustacei Weresub \& Illman (Weresub, Illman 1980) causing their decay. Rare cases are associations of fruitbodies with chitine invertebrate debris, like Hyphoderma setigerum (MSK 4431b), in which thickened up to $7 \mathrm{~mm}$ basidioma tightly embraces, incorporates in and grows through big chitine exoskeletons of an unidentified insect. The using of living nematodes as nutritive substratum is a scarcely investigated fact, known for probable $H y$ phoderma sp. with stephanocysts (Lio u, Tze an 1992). Single species was described from dung - Dacryobasidium coprophilum (Wakef.) Jülich, but it can also colonize leaves and twigs (Jülich 1984). Two species of Trechispora, T. polygonospora Ryvarden and T. spinulifera Jülich were found on termitaries (D o m a ń s ki 1992). Hypochnicium eichleri (Bres.) J. Erikss. \& Ryvarden was collected once on earth-worm excrements (Eriksson, Ryvarden 1976), which can be indeed classified as a type of humus substratum.

Should be mention that Serpula lacrymans can grow on different artificial seminatural (fibre board, gypsum plates, wallpaper, textiles) and synthetic (polyurethane foam) materials (B e ch-Andersen 2005). We observed this fungus on old book (ex CWU sine No.).

\section{CONCLUSION}

The data accumulated in literature and by us show that the range of substrata for corticioid fungi in situ includes all types of terrestrial plant bodies, both living and dead, other fungi, both lichenized and non-lichenized, humus, mineral bodies, and in exclusive cases invertebrates and shallow water submerged plant debris. Our ob- 
servations demonstrated that typically wood-inhabiting fungi can be found on different non-woody substrata. In most cases these are the particles attached or adjacent to decaying wood or bark. Some litter fungi, especially those with rhizomorphs of hyphal cords, have the ability to cover any meeting substratum. Frequently fungi colonize living mosses near wood or bark surface with outer observing negative effect on them. Lichens and algae are much less documented substrata for Corticiaceae s. 1. than other cryptogams (mosses and ferns). Colonization of different kinds of artificial mineral, semi-natural, and synthetic materials is still known for house fungi only, especially for Serpula lacrymans.

Acknowledgements: The work was partly supported by grant B05 171 of Belarusian Republican Fund for Fundamental Research. I am grateful to Hbl. Dr G.F. Rykovsky (V.F. Kuprevich Institute of Experimen tal Botany, Minsk) for identifications of some Bryophyta and to Dr D.I. Tret'yakov (the same institution) for identifications of some vascular hosts. I am thankful to Mr. A.Yu. Akulov (Mycology and Plant Resist ance Department, Kharkiv National University, CWU Myc herbarium) for giving a duplicate of Serpula lacrymans growing on book.

The materials of this paper were partly presented as poster at XIV Congress of European Mycologists. I met Prof. Alina Skirgiełło first there and she become interested in my research into interaction of corticioid fungi with other organisms. Thanking in that number to this meeting the materials become summarized and promulgated.

\section{REFERENCES}

A andstad S., Ryvarden L. 1987. Aphyllophorales on wooden fences in Norway. Windahlia 17: 4954.

Bech Andersen J. 2005. The true dry rot fungus, Serpula lacrymans. History, occurrence in nature and distribution in Europe. (In:) V.G. S tor ozh e n k o, V.I. Krut tov (eds). Problems of forest phyto pathology and mycology. Proceedings of the 6th International Conference. Moscow, Petrozavodsk: Forest Research Institute of Karelian Research Centre RAS. P. 3443.

Besl H., Helfe r W., Lu schka N. 1989. Basidiomyceten auf alter Porlingsfruchtkörpern. Ber. Bayer. Bot. Ges. 60: 133145.

Binder M., Hibbett D.S., Larsson K. H., Larsson E., Langer E., Langer G. 2005. The phy logenetic distribution of resupinate forms across the major clades of mushroom forming fungi (Ho mobasidiomycetes). Systematics and Biodiversity 3 (2): 113157.

Bondartsev A.S. 1948. On the distribution of house fungi in Leningrad over last years (1940 1946). Priroda 11: 3742.

Daniels J. 1963. Saprophytic and parasitic activities of some isolates of Corticium solani. Trans. Brit. Mycol. Soc. 46 (4): 485502.

Domański S. 1988. Mała flora grzybów. Basidiomycetes (Podstawczaki). Aphyllophorales (Bezblasz kowce). 5. Corticiaceae: Acanthobasidium Irpicodon. PWN, Warszawa Kraków, 427 pp.

D o m a ń s k i S. 1991. Mała flora grzybów. I. Basidiomycetes (Podstawczaki). Aphyllophorales (Bezblasz kowce). Stephanosporales (Stefanosporowce). 6. Corticiaceae: Kavinia Rogersella, Stephanospora ceae: Lindtneria. PWN, Warszawa Kraków, 272 pp.

Domański S. 1992. Mała flora grzybów. I. Basidiomycetes (Podstawczaki). Aphyllophorales (Bezblasz kowce). 7. Corticiaceae: Sarcodontia Ypsilonidium, Christiansenia and Syzygospora. W. Szafer Insti tute of Botany, Polish Academy of Sciences, Kraków, 258 pp.

Eriksson J., Ryvarden L. 1973. The Corticiaceae of North Europe. Vol. 2: Aleurodiscus Conferto basidium. Oslo: Fungiflora. P. 60286.

Eriksson J., Ryvarden L. 1976. The Corticiaceae of North Europe. Vol. 4: Hyphodermella Mycoa cia. Oslo: Fungiflora. P. 547886.

G u n nell P.S., Webste r R.K. 1987. Ceratobasidium oryzae sativae sp. nov., the teleomorph of Rhizoc tonia oryzae sativae and Ceratobasidium setariae comb. nov., the probable teleomorph of Rhizoctonia fumigata comb. nov. Mycologia 79 (5): 731736.

Hawksworth D.L., Kirk P.M., Sutton B.C., Pegler D.N. (eds) 1995. Ainsworth and Bisby's dic tionary of the fungi. 8 th ed. Wallingford: CAB International. $616 \mathrm{pp}$. 
Hj ortst a m K., La r s s o n K. H. 1997. Corticioid fungi growing on ferns in northern Europe. Windahlia 22: 4955.

Hjortstam K., Lars on K. H., Ryvarden L. 1988. The Corticiaceae of North Europe. Vol. 8: Phle biella, Thanatephorus Ypsilonidium. Oslo: Fungiflora. P. 14501631.

Jülich W. 1984. Die Nichtblätterpilze, Gallertpilze und Bauchpilze. Aphyllophorales, Heterobasidio mycetes, Gastromycetes. (In:) H. G a m s (ed.) Kleine Kryptogamenflora. Band IIb/1. Basidiomyce ten. 1. Teil. Stuttgart, N.Y.: G. Fischer. 626 pp.

Kirk P.M., Cannon P.F., David J.C., S talpers J.A. (eds) 2001. Ainsworth and Bisby's dictionary of the fungi. 9th ed. Egham, Wallingford: CAB International. $655 \mathrm{pp}$.

Kõljalg U. 1996. Tomentella (Basidiomycota) and related genera in temperate Eurasia (Synopsis Fun gorum. Vol. 9). Oslo: Fungiflora, 1996. 213 pp.

Kotiranta H., S a re noks a R. 1993. Rare Finnish Aphyllophorales (Basidiomycetes) plus two new combinations in Efibula. Ann. Bot. Fennici 30: 211249.

Liou J.Y., Tzean S.S. 1992. Stephanocysts as nematode trapping and infecting propagules. Mycologia 84 (5): 786790.

Nakas on e K.K., Gilberts on R.L. 1978. Cultural and other studies of fungi that decay ocotillo in Arizona. Mycologia 70 (2): 266299.

Parm a s to E., Nilsson H., Larsson K. H. 2004. Cortbase version 2. Extensive updates of a nomencla tural database for corticioid fungi (Hymenomycetes). Phyloinformatics 1: 5.

Punja Z.K., Grogan R.G., Adams G.C. 1982. Influence of nutrition, environment, and the isolate on basidiocarp formation, development, and structure in Athelia (Sclerotium) rolfsii. Mycologia 74 (6): 917926.

Reid D.A. 1969. New or interesting British plant diseases. Trans. Brit. Mycol. Soc. 52 (1): 1938.

Ry paček V. 1967. Biologie dřevokazných hub [Wood decay fungi biology. A translation of Czech edi tion, expanded and supplemented by the author. Translated by M. Gashkova, edited by A.T. Vanin]. Moscow: Lesnaya promyshlennost'. $276 \mathrm{pp}$.

de Silva R.L., Wood R.K.S. 1964. Infection of plants by Corticium solani and C. praticola effect of plant exudates. Trans. Brit. Mycol. Soc. 47 (1): 1524.

Tu C.C., Cheng Y.H., Kimbrough J.W. A new species of Thanatephorus from jute in Taiwan. Myco logia 69 (2): 409413.

Tu C.C., Hsieh T.F., Tsai W.H., Kimbrough J.W. 1992. Induction of basidia and morphological comparison among isolates of Athelia (Sclerotium) rolfsii. Mycologia 84 (5): 695704.

Warcup J.H., Talbot P.H.B. 1963. Ecology and identity of mycelia isolated from soil. II. Trans. Brit. Mycol. Soc. 46 (4): 465472.

Warcu p J.H., Talb ot P.H.B. 1966. Perfect states of some rhizoctonias. Trans. Brit. Mycol. Soc. 49 (3): 427435.

We re sub L.K., I11 m a W.I. 1980. Corticium centrifugum reisolated from fisheye rot of stored apples. Can. J. Bot. 58: 137146.

Yurchenko E.O. Corticioid fungi on mosses in Belarus. Mycena (1) 1: 7191.

Yurchenko E.O., Golubkov V.V. 2003. The morphology, biology, and geography of a necrotrophic basidiomycete Athelia arachnoidea in Belarus. Mycological Progress 2 (4): 275284.

Yur chen ko E.O., Z m it r ovi c h I.V. 2001. Variability of Hyphoderma setigerum (Corticiaceae s. 1., Ba sidiomycetes) in Belarus and northwest Russia. Mycotaxon 78: 423434.

\section{Naturalne substraty dla grzybów korticjoidalnych}

\section{Streszczenie}

Autor podaje przegląd typów substratów zasiedlanych przez grzyby nieporoidalne przytacza jąc przykłady z literatury i własnych obserwacji na Białorusi. Jako podłoża dla grzybów wyróżnia drzewa, krzewy i zielne rośliny naczyniowe, mszaki, glony, grzyby zlichenizowane i niezlicheni zowane, a także śluzowce i bezkręgowce. Grzyby występują na żywych i obumarłych, w różnych stadiach rozkładu organizmach oraz ich częściach. Ponadto grzyby znane są jako występujące na glebie, próchnicy, skałach, sztucznych, syntetycznych materiałach oraz na odchodach. 